\title{
H.G. WELLS AND THE NEW LIBERALISM ${ }^{1}$
}

\section{Richard Toye \\ University of Exeter \\ R.Toye@exeter.ac.uk}

ABSTRACT: This article offers a new interpretation of H.G. Wells's political thought in the Edwardian period and beyond. Scholars have emphasised his socialism at the expense of his commitment to liberalism, and have misread his novel The New Machiavelli as an anti-Liberal tract. Wells spent much effort in the pre-1914 period in the quest for a 'new Liberalism', and did not believe that socialists should compete directly with the Liberal Party for votes. It was this latter conviction that lay behind his much misunderstood dispute with the Fabian Society. His political support for Churchill was one sign of his belief in the compatibility of liberalism and socialism, in which he was far from unique at the time. He also engaged, somewhat idiosyncratically, with the 'servile state' concept of Hilaire Belloc. Although he did not articulate his Liberal identity with complete consistency, he did so with increasing intensity as World War I approached. This helps explain why key New Liberal politicians including Churchill, Lloyd George and Masterman responded to his ideas sympathetically. The extent of engagement between Wells and the 'New Liberalism' was such that he deserves to be considered alongside Green, Ritchie, Hobson and Hobhouse as one of its prophets. 
In May 1910, H.G. Wells contributed a letter to the first issue of the official journal of the National League of Young Liberals. He wrote: 'I am known as a Socialist, but I have never ceased to be a Liberal - which is not exactly the same thing as a member of the Liberal party. Liberalism stands to socialism as the soul to the body.' $\mathrm{He}$ concluded his letter: 'I tried to Liberalise the Fabian Society - ah well! That is a matter for the past. ${ }^{2}$ The same week, in an interview with The Labour Leader, he endorsed Liberal MP Hilaire Belloc's harsh criticisms of the Prevention of Destitution Bill, which had been designed to implement Sidney and Beatrice Webb's proposals for the break-up of the poor law. (The Bill had no hope of being passed). 'It might be only too easy for such a measure to be used to replace the present pauper classes by classes of State labourers with an essentially servile status', Wells declared. ${ }^{3}$ John Burns, the Liberal government's insufferably complacent President of the Local Government Board, sent him a letter to congratulating him on these 'first rate' interventions. 'The new helotry in the Servile State run by the archivists of the [London] School of Economics means a race of paupers in a grovelling community ruled by uniformed prigs', Burns wrote. 'Rely upon me saving you from this plague. ${ }^{4}$

It might seem that Wells's attacks on the Webbs and their Fabian colleagues were simply a case of sour grapes. After all, during his dispute with the Fabian Society, which had culminated in his resignation from it in 1908, he had placed much emphasis on the importance of it 'making socialists'. How, then, could he now argue that he had been trying to 'Liberalise' it? Yet, as will be seen, his claim was by no means wholly spurious. Throughout the Edwardian period - albeit not with complete consistency - he did articulate his identity as a Liberal, and at times placed more emphasis on this than on his socialism. Not only did he share many traits in common 
with a number of 'advanced Liberals' within the party's ranks, he was also an influence upon them. The extent of the engagement between Wells and the New Liberalism' has never been recognised, but he deserves to be considered alongside T.H. Green, D.G. Ritchie, J.A. Hobson and L.T. Hobhouse as one of its prophets. That is not to say that he was as an original thinker on the topic of liberalism as they were, but rather that he was an important populariser of New Liberal ideas, and had a demonstrable impact upon key Liberal politicians.

The Edwardian period was a crucial one for Wells. He had made his name in the 1890s as the author of 'scientific romances' such as The Time Machine (1895), The Invisible Man (1897) and The War of the Worlds (1898). Although he did not now abandon the science fiction genre, he turned also to 'social' novels such as Love and Mr. Lewisham (1900), Kipps (1905), Tono-Bungay (1909) and The History of Mr. Polly (1910). In addition, he published Anticipations (1901), his first book of futurological predictions; and through this and other writings, including Mankind in the Making (1903) and A Modern Utopia (1905), he established himself as a social and political commentator. He argued for the creation of a 'New Republic', in which individuals would have a clear sense of their co-operative share in society's conscious preparation for the future, rather than, as in the past, such preparations taking place unconsciously through their self-seeking behaviour. ${ }^{5}$ These were, moreover, tumultuous years in Wells's private life. Most notoriously, his lovers included Amber Reeves, the daughter of the social reformers, William and Maud Pember Reeves, with whom he was on terms of friendship. Knowledge of his private life had an impact on how his ideas about love, marriage and the family were received. The Spectator's 
violently denunciatory review of his 1909 novel Ann Veronica, the heroine of which was a liberated young woman, was a case in point. ${ }^{6}$

Wells's Edwardian writings cannot be properly understood without reference to the turbulent political climate in which they were created. After a long wilderness period, the Liberal Party at last regained office under Sir Henry Campbell-Bannerman at the end of 1905. Its electoral pact with the nascent Labour Party helped cement its landslide victory at the ensuing general election. The new government was to face many crises, notably over Ireland, the House of Lords, votes for women, and the military challenge posed by Germany; and there was also the spectre of industrial unrest. However, it also showed great reforming energy, especially after H.H. Asquith replaced Campbell-Bannerman as Prime Minister in 1908. Liberalism had for some time been in the grip of a collectivist turn, under the influence of thinkers such as Green (1836-1882), Ritchie (1853-1903), Hobhouse (1864-1929), and Hobson (1858-1940). Individualism was not rejected, but there was a quest to bring personal freedom into harmony with the good of society as a whole. By promoting the latter, it was argued, individual freedom could actually be accentuated. ${ }^{7}$ These concerns (which were also reflected extensively in the work of Wells) suggested the need for greater state involvement in the welfare of the citizenry. There is some difficulty in establishing a direct line of causation between these changing patterns of thinking amongst intellectuals and the actual social legislation introduced by practicing politicians. Nevertheless, the Liberal government's reforms were prolific, and included the introduction of old age pensions, national insurance against sickness and unemployment, as well as significant extensions of state responsibility for the welfare 
of children - the last being an issue which, it should be noted, was a particular concern of Wells.

In the extensive literature on Wells there is no shortage of debate about whether he was a libertarian thinker or an authoritarian one; and it has rightly been recognised that (as indeed was true of the 'classic' New Liberal thinkers) there was a powerful tension between his competing individualistic and collectivist instincts. ${ }^{8}$ What is missing, though, is any meaningful account of Wells's interaction with Edwardian liberalism or of his view of the specific reforms it promoted. ${ }^{9}$ As it is taken as axiomatic that he presented 'a fundamentally socialist doctrine of reform, ${ }^{10}$ his attitude to the Liberal Party, when mentioned at all, is skated over with minimal comment. ${ }^{11}$ It is assumed that the Webbs were 'his only plausible political allies' in Edwardian England, ${ }^{12}$ and that he was anti-Liberal. ${ }^{13}$ Because (with some justification) he is assumed to have been a Utopian, long-run thinker, his views about how contemporary socialists should deal with the Liberal party, in a short-term, practical sense, have not received the attention they deserve. Because his major attempt at political cooperation with others - the Fabian Society episode - ended in failure, and because that failure was due in part to his own highly egotistical behaviour, his other political interventions have been written off as the actions of a maverick. Thus, although biographies of him include some useful information about his political entanglements in this period, a convincing analysis of them is quite lacking. ${ }^{14}$ Geoffrey West made a few brief, pertinent observations in H.G. Wells: sketch for a portrait (1930), but these have not been followed up by the major, scholarly biographers. ${ }^{15}$ 
At the same time Wells has been neglected in the literature on the New Liberalism. There is an acknowledgement that his much-debated interest in eugenics was a concern he held in common with other 'progressive' thinkers. ${ }^{16}$ (He was heavily influenced by T.H. Huxley, and there are strong similarities between his views on the relationship between evolution and social progress and those of many New Liberals.) ${ }^{17}$ His novels are also acknowledged as important, both because of their reflection of widely held social concerns and because of the penetrating description of the Edwardian political-social milieu in The New Machiavelli (1911). ${ }^{18}$ There is no hint, though, of Wells's impact on reforming politicians, notably Winston Churchill, David Lloyd George, C.F.G. Masterman and Leo Chiozza Money. This is doubtless because, in the absence of a proper appreciation of Wells's attitude towards political liberalism, the idea of such influence seems profoundly counter-intuitive.

This article does not aim at a comprehensive treatment of Wells's view of the state, a theme tackled in depth by other writers. Rather, it will demonstrate that prior to World War I, Wells repeatedly articulated a political strategy of cooperation between socialism and liberalism. He believed that socialists should not organise electorally outside the framework of the 'progressive alliance' between Liberals and Labour. Radical Liberals should be encouraged in the direction of socialism, but they should not be antagonised through socialist opposition at the polls. Furthermore, Wells's broader political message - or parts of it - did find a welcome amongst radical Liberals. This was possible because, although his ultimate vision was grandiose, he did not disdain incremental reforms of the kind that the government enacted. He also engaged seriously with aspects of contemporary liberal thought. If the New Liberalism is to be understood less as a fixed set of principles than as a quest to 
resolve the tensions between personal freedom and the collective good, then Wells should be regarded as an important part of the picture. If he was never a mainstream Liberal figure, he certainly had much in common with the party's 'advanced' wing, and his ideas provoked interest even in some staid and apparently unpromising quarters of the government.

Wells's ideas must of course be understood in relation to those of the many contemporary socialists emphasised the links between liberalism and socialism. ${ }^{19}$ On the one hand there were those, like Ramsay MacDonald, who claimed that socialism was a stage that followed liberalism and retained everything of value in it whilst progressing onwards from it. ${ }^{20}$ In this analysis, political cooperation with organised liberalism might well be desirable in the present, but Liberals ought not to take its continuation on trust, and socialists should prosecute their own policy regardless of the consequences for other parties. ${ }^{21}$ On the other hand, there were those who, like Wells, believed in the need for an organic and continuing relationship between socialism and liberalism. This view helped facilitate the fluid political identities of figures such as Percy Alden, E.D. Simon and Ben Keeling, who tended to see their Liberal and Fabian sympathies as compatible with one another. ${ }^{22}$ Both approaches helped smooth the path of Liberals towards the Labour Party after 1918, but it should be stressed that before the war there were plenty of socialists who did not see the eclipse of the Liberal Party as either inevitable or desirable. Therefore, to describe Wells as a New Liberal is not in any way to diminish the importance of his socialism (although the importance that he himself attached to it changed over time). Rather, it is to draw attention to a key aspect of his thought, and to situate him more firmly within the political world in which he was moving. 


\section{Wells and the Fabians: a reassessment}

Wells had shown an interest in socialism as a science student in London in the 1880s, and in 1886 gave a debating society paper on 'Democratic Socialism', the 'cornerstone' of which he defined as 'the merging of the individual in the State'. ${ }^{23}$ In Anticipations he wrote: 'Liberalism is a thing of the past, it is no longer a doctrine, but a faction. There must follow some newborn thing. ${ }^{24}$ There has been a tendency to conclude that this 'newborn thing' was socialism, and indeed in 1906 he himself claimed that he was a socialist of long standing. ${ }^{25}$ However, an October 1901 letter from Wells to the journalist and editor W.T. Stead casts a different light on his thought as it stood at that time. Anticipations, he wrote, was 'designed as a sketch of a possible new Liberalism, that I have sufficient confidence to believe might very usefully supersede the chaotic good intentions that constitute contemporary Liberalism. ${ }^{26}$ He frequently identified himself as a Liberal, albeit one who wanted to see orthodox Liberalism reformulated. A month after his letter to Stead he wrote to Winston Churchill (then a Tory MP): 'I do sincerely believe that Liberalism (as Gladstone knew it) is as dead as Adam and that there is an urgent need for an ordered body of doctrine that will secure for the scattered good intentions that are the soul of Liberalism to come together upon. ${ }^{27}$ A few weeks later he wrote to his friend Graham Wallas: 'I am (by your grace) a natural Liberal (?new variety in himself even a sub species?)'. ${ }^{28}$ Some months after that, he enquired from Wallas if the Political and Economic Circle of the National Liberal Club was worth belonging to, and went on to join the Club itself. ${ }^{29}$ In November 1902, Beatrice Webb invited Wells to join the CoEfficients, a cross-party dining club whose members included, amongst others, the prominent Liberal politicians R.B. Haldane and Sir Edward Grey, as well Charles 
Masterman, who was not yet an MP but was making a name for himself as journalist and reformer. ${ }^{30}$ It is perfectly possible that Wells did see himself as a socialist at this stage, but so it must have been on the basis that he thought socialism and revivified liberalism were mutually compatible.

Wells took a strong and approving interest in contemporary works of social investigation, including those of Charles Booth and Seebohm Rowntree, which formed a key part of the intellectual background to the later Liberal welfare reforms. ${ }^{31}$ One of his key goals was 'to get better births and a better result from the births we get'. To this end, he advocated specific reforms, such as a minimum wage and a stateguaranteed 'Minimum Standard of Life', and the extension of the death duties introduced by the previous Liberal government. ${ }^{32}$ In his Modern Utopia he depicted a world ruled over by 'voluntary noblemen' known as 'Samurai'. A less fanciful aspect of Utopia was that 'the State will insure the children of every citizen, and those legitimately dependent upon him, against the inconvenience of his death ... and it will insure him against old age and infirmity.' The book also places great emphasis on child welfare. It further envisaged a minimum wage, labour exchanges and contracyclical public works:

All over the world the labour exchanges will be reporting the fluctuating pressure of economic demand and transferring workers from this region of excess to that of scarcity; and whenever the excess is universal, the World State-failing an adequate development of private enterprise-will either reduce the working day and so absorb the excess, or set on foot some permanent special works of its own, paying the minimum wage and allowing them to progress just as slowly or just as rapidly as the ebb and flow of labour dictated. 
The Samurai aside, such reform proposals were not original to Wells. Nor, indeed, were they the exclusive preserve of Liberals. But they were not far removed from the agenda that was to be taken up in due course by the new Liberal government. ${ }^{34}$

Wells had a divided view of the Liberal Party itself. He was contemptuous of official Liberalism, hence his scathing remarks about its leader, the heartily traditionalist Sir Henry Campbell-Bannerman. ${ }^{35}$ However, he took a positive attitude towards younger, radical MPs such as Charles Trevelyan. Trevelyan was a member of the Rainbow Circle, a progressive discussion group that counted many New Liberals among its number. In May 1905 he wrote to Wells praising Anticipations. ${ }^{36}$ Wells wrote back saying he would welcome an exchange of views: 'I'm pretty keenly interested in what the new series of liberals is thinking \& you are one of the most promising and representative. ${ }^{37}$ He subsequently told Trevelyan that the Liberal leaders annoyed him not 'because they're not great personalities but because they've no ideas'. ${ }^{38}$

Wells joined the Fabian Society in February 1903, although he remained for the time being a rather inactive member. ${ }^{39}$ He dropped, for the time being, his claim to be a Liberal. He now argued that advocates of the New Republic should not call themselves Liberals or Conservatives. ${ }^{40}$ But he had not abandoned an interest in Liberal causes, such as opposition to Chinese labour in South Africa ${ }^{41}$ He was also much impressed by the work of Leo Chiozza Money, a radical author and journalist who was to be elected in 1906 as Liberal MP for North Paddington. Though neglected today, Money was a seminal (if idiosyncratic) figure in Edwardian political economy, not least through his work Riches and Poverty (1905). ${ }^{42}$ The book provided a vivid illustration of the stark inequalities of income distribution in Britain, and impressed 
Wells as being 'extraordinarily valuable and suggestive'. ${ }^{43}$ In December 1905, just as the new government was being formed, Wells wrote to Money to say how much he admired the book, adding that he had quoted a passage in an article published in the Independent Review. (The article in question, 'This Misery of Boots', was later published as a Fabian tract.) He also told Money of his plan to 'revive the youth of the Fabian Society and set a propaganda going among the student class and the middle class youth generally in London. ${ }^{44}$ In launching this campaign, Wells also hoped to bring advanced Liberals such as Money firmly into the socialist fold.

Wells's famous controversy with the Fabian Society now began. According to Edward Pease, the Society's secretary and its first historian, the convulsions that Wells's intervention prompted were the product of personality rather than principle. ${ }^{45}$ For the most part, subsequent writers have followed this interpretation, although they have differed as to whether it was Wells or the Fabian 'Old Guard' he confronted who were most at fault. ${ }^{46} \mathrm{~A}$ few have hinted that something more profound than personalities was at stake, but - perhaps deceived by a misleading remark in Wells's memoirs - they have largely failed to get a handle on what this actually was. ${ }^{47}$ Undoubtedly - as the standard accounts stress - there was much debate about how the Society should best be organised. And undoubtedly, Wells did enflame things through his 'natural impatience with committees and procedure' and his general unreliability. ${ }^{48}$ What has never been recognized, though, is the nature of the fundamental difference in attitude between Wells and George Bernard Shaw, who was one of his key antagonists amongst the 'Old Gang'. Wells believed that liberalism and socialism were fundamentally compatible; Shaw believed they were irreconcilable. Wells, furthermore, believed that the Fabians should not undertake independent 
electoral activity; Shaw believed that they should, in order to establish a middle class socialist party of their own. The lines of division on these questions within the society became blurred, because both men had to take into account the differing views of their own allies; but they were genuine and significant.

Wells's attack on the Old Guard was made in his paper The Faults of the Fabian, given on 9 February 1906. It included some colourful and much-quoted denunciations of the Society's ideological exclusivity, its 'insidious' policy of permeation of existing institutions, and its unwillingness to advertise itself. 'Make socialists and you will achieve socialism', Wells declared; 'there is no other way. ${ }^{49}$ It also argued that the society's 'Basis' (a statement of socialist beliefs, to which members had to subscribe) should be redrafted, as the existing one was 'likely to deter all sorts of wavering people who might otherwise come into the society and be converted into good socialists. ${ }^{50}$ What has attracted less attention is Wells's insistence that the Fabians should concentrate their propaganda on the educated middle classes. ${ }^{51}$ (This casts doubt upon the suggestion that Wells was motivated by 'resentment against the middle class'.) ${ }^{52}$ The implications of Wells's arguments were twofold. First, if the Basis was to be made less exacting, the more likely it was that middle class advanced Liberals would be able to subscribe to it. Second, if the Society was to concentrate on 'making socialists' to the exclusion of all else, this meant that it would not be sponsoring parliamentary candidates and thus competing for seats with Liberals. Wells's belief in cooperation with advanced Liberals was further demonstrated a few months later, when he wrote once more to Chiozza Money: 'I do wish you'd come in with me and try and broaden out and energize [?] the Fabian Society. Well, anyhow if you won't I'm still very much yours. ${ }^{53}$ 
As a consequence of Faults of the Fabian a Special Committee, on which Wells was to sit, was established to consider his reform proposals. In addition to recommending organisational changes and a redrafted Basis, its report - which was debated by the Society over two meetings during December 1906 - 'warmly' endorsed 'the conception of Socialists, whenever possible, declaring themselves as Socialists, criticising both Liberalism and Conservatism in equal measure, and standing as Socialists in municipal and parliamentary elections. ${ }^{54}$ Pease later noted that this 'one constructive proposal' was 'quite alien to Mr. Wells's original ideas; it was forced on him, it is said, by other members of his Committee and was described by himself later on as "secondary and subordinate.",55 Ironically - and it is here that the lines of division became blurred - Shaw was in favour of the idea. In advance of the debate on the committee's report, he wrote to Sidney Webb urging him not to be concerned at what he saw as a demand for a new socialist party. 'It is clear to me that we must consummate the Fabian section of our lives by setting on foot a Fabian parliamentary party', he wrote, and anticipated that there would soon 'be the beginnings of a big middle class demand for an educated middle class handling of the new problems in Parliament.' Moreover, 'It seems eminently probable that Wells, instead of embracing our go-ahead proposal, will jib at it, just as some of the other stalwarts, after clamoring for an independent Socialist Party, will quiet down considerably when we bring them right up against it. ${ }^{56}$ In other words, Shaw seems to have grasped that Wells, whilst wishing to appeal to the middle classes, opposed trying to organise them electorally. 
This difference of opinion was masked when the report was debated, because Wells insisted on trying to turn the discussions into a vote of no-confidence in the Fabian Executive, which was dominated by Shaw, Webb and other members of the 'Old Gang'. Shaw managed to defeat Wells by making it clear that he and his colleagues would resign if Wells's proposals were accepted. Wells did emphasise he disagreed with the idea of a new middle class party: 'the Parliamentary rôle for us to play in the near future - whatever our remoter prospect may be - is no whimsical, mischievous independence, but that of a force loyally brigaded with the I.L.P. [Independent Labour Party] in the cause of political Socialism. ${ }^{57}$ (The ILP, unlike the Labour Party to which it was affiliated, was committed to the common ownership of the means of production.) This remark can only be fully understood, though, if it is appreciated that he did not consider that the ILP should be opposed to the Liberals. Indeed, in 1908 he said that he regarded 'the almost fanatical anti-Liberalism of some members of the Independent Labour Party, as mischievous stupidity’. ${ }^{58}$

Although Wells had been defeated, he did not yet leave the Fabians; nor did the issue of a middle class party go away. He stood in the elections for the Executive that took place in 1907. He and his supporters emphasised that 'the Fabian Society should continue to act loyally with the Labour Party and assist in developing it into a Socialist Party' and stated their opposition to 'the setting up of a new Socialist political organisation'. 59 The manifesto of the 'Old Gang' slate was rather mealymouthed, but emphasised the importance of the Society remaining independent, and stressed that it should not oppose 'the formation of a new and definitely Socialist Party fully representing the middle-class proletariat, should such a step prove necessary. ${ }^{60}$ (A discarded section of the manifesto, apparently drafted by Shaw, 
called overtly for a new party, provisionally called 'an Independent Socialist Party to emphasise its independence of the Labour Party'). ${ }^{61}$ The ballot papers were sent out during March 1907, and Wells was in due course elected to the Executive - the 'Old Gang' not having run a full slate. ${ }^{62}$ Meanwhile, the Society's affairs were being discussed in the Liberal press, which served to bring out Wells's pro-Liberal position more clearly.

In March, an editorial in the Daily News attacked the Fabian Society as 'undemocratic', arguing that its philosophy 'repudiated self-government in favour of a system of efficiency imposed from outside. ${ }^{63}$ Shaw wrote in to ask if the article should be taken 'as a declaration of war' on socialism, adding: 'The question is important, because there is an irreconcileable antagonism between Liberalism and Socialism. ${ }^{64}$ Wells then wrote in turn, denying that Shaw was representative of the Society as a whole: 'his exposition of the irreconcileable gulf between Liberalism and the Fabian Society is just an intellectual freak for which we are not responsible. There is no such gulf. There are the closest links in sympathy and personality between the Liberal left and the Fabian Society. ${ }^{65}$ At the end of the month, The Nation praised the 'gallant endeavour of Mr. H.G. Wells and his reforming friends to pump oxygen into the body of Fabianism' but attacked the 'anti-democratic attitude' of the Fabian leaders. Shaw was described as the society's 'evil genius'. ${ }^{66}$ Wells responded with a letter that ridiculed the idea that either Shaw or Sidney Webb was evil, yet which also denied that they were truly representative of Fabianism. He hoped, he said, that The Nation's article would 'do much to induce those Socialists and Socialistic thinkers who constitute the left wing of the Liberal Party to consider very seriously the advisability of joining us in our work.' Broad-minded observers should not reject the 
Society because of Shaw's influence but rather diminish that influence by 'coming in to redress our balance. ${ }^{67}$ Wells also emphasised the compatibility of liberalism and socialism in his private letters. To one correspondent he wrote that 'nothing could so effectively play the game for financial adventure as to make a break between Socialists \& Socialist Programmes \& Liberals'. ${ }^{68}$ To another he denied that 'socialism was a fundamentally different thing from Progressive Liberalism. ${ }^{69}$

The complement of these beliefs was his continued insistence that the Fabian Society should remain a 'factory of ideas' rather than intervene in elections. In May, he sent a circular to a sample of its members, asking them to sign a document that 'if anything, it [the Society] should abandon rather than increase its present limited intervention in the direction of the Labour Party, and it should abstain from any share whatever in the development of any fresh political socialist organization. ${ }^{70} \mathrm{He}$ followed this up with an article in the socialist weekly paper The New Age: 'I do not believe there is any practical good at all to be achieved at the present time by Socialist politicians working in a party professing to be a Socialist party, and I believe they may do an enormous amount of mischief to the Socialist cause.' Moreover, 'The object of the Socialist propagandist is not to persuade people to give up convictions and abandon links, but to develop them, to develop them into an ampler conception of the State and of social development. ${ }^{71}$ In January 1908 he expounded on the point further. 'I have never believed that a Socialist Party could hope to form a Government in this country in my life-time', he wrote. He went on to argue that, unless his Fabian colleagues entertained 'so remarkable a hope', they must necessarily 'contemplate a working political combination between the Socialist members in Parliament' and the 'noncapitalist section of the Liberal Party'. ${ }^{72}$ In his autobiography Wells claimed to have 
envisaged a 'reconditioned Fabian Society as becoming $[\ldots]$ the directive element of a reorganized socialist party. ${ }^{, 73}$ It is easy to see that this was far from the truth.

Wells's beliefs, as stated in The New Age, do much to make sense of an episode that followed. This was his decision to support Winston Churchill in the April 1908 NorthWest Manchester by-election. Churchill was opposed by William Joynson-Hicks, a Conservative, and by Dan Irving, a socialist, who was backed by the Social Democratic Party. ${ }^{74}$ Wells weighed in publicly on Churchill's side, with a letter to the Daily News, in which he urged voters to support him rather than Irving. The typical explanation for this is that Wells was motivated by his deep animus against JoynsonHicks, who had earlier criticised him as an advocate of free love - or by personal regard for Churchill. ${ }^{75}$

Personal factors cannot, it is true, be dismissed entirely. But more importantly - as will be seen later - Wells had good reason to believe that Churchill was sympathetic to his own views. Moreover, his letter to the News demonstrates that he was particularly impressed by a recent article Churchill had written in The Nation, which argued for the establishment of a 'Minimum Standard' of living through state action. ${ }^{76}$ Wells was also acting consistently with the view he had previously laid out in the New Age, i.e. that for socialists to compete electorally with the established parties would antagonise the "very wide borderland of tepid believers and the half-converted'. ${ }^{77}$ Even though the Liberal Party was 'strongly tainted by the memories of Victorian individualism', Churchill could be supported because his of his 'active and still rapidly developing and broadening mind' and because he had demonstrated 'a spirit entirely in accordance with the spirit of our [socialist] movement. ${ }^{, 78}$ This last remark 
was clearly wishful thinking, but Wells's overall line was consistent with his own previously stated opinions, and was part of a considered strategy. At the same time that strategy was at odds with the views of the majority of the Fabian Society, which in January had resolved to run its own candidates for Parliament (although the idea never took off). Accordingly, at the Fabian AGM in April, Wells was reprimanded for having supported Churchill. ${ }^{79}$ He subsequently justified himself in an article published in The Socialist Review, arguing that Labour could only progress through co-operation with another major party, and incidentally revealing the interesting fact that he himself was a member of the ILP. (It is unclear how long his membership lasted.)

The Liberal Party, in spite of a strong individualist tradition, develops more and more distinctly constructive elements, and contains a proportion of genuine Socialists second only to that in the Labour Party. Moreover, it produces a type of politician whose social and administrative experience will be absolutely necessary to the composition of the first Socialist government. [...] It cannot be too clearly recognized that the Labour Party is not a party coextensive with the Liberal and Conservative Parties. These latter fight over practically the whole country; the former never has and never will. Whatever practical legislative work it wants to get done, therefore, must be done, can only be done, through an understanding with one or other of the two national parties. ${ }^{80}$

Although Wells was re-elected to the Fabian Executive, his interest in the Society was now waning. One of his last efforts to reform it was made in March 1908, when he tried his hand at a new draft Basis. Much of the first part of this concentrated on 'the duty of the State [...] to direct, to inquire, and to intervene in any default for the child's welfare.' Only later did it move on to the evils of private property. ${ }^{81}$ Hence Shaw's sarcastic comment that it contained 'a devil of a lot of Liberal Children's Bill to a very little Socialism and no Democracy [...] Most really sound Anglican Tories would sign it as it stands. ${ }^{, 82}$ In September, having made no progress, Wells resigned 
from the Society on the grounds that he was not in sympathy with the existing Basis. His 'chief objection' to it was 'its disregard of that claim of every child upon the State which is primary and fundamental to my conception of socialism. ${ }^{83} \mathrm{He}$ did not make an explicit issue of the relationship of liberalism to socialism. However, it seems - as Shaw had suggested - that his position on child welfare was not far from that of the Liberal government, which was legislating to extend state powers in this sphere, and that in this he was out of step with Fabian opinion. ${ }^{84}$ Wells's subsequent scathing comments on such legislation in The New Machiavelli cannot be taken completely at face value.

Wells's Fabian phase had demonstrated that, although his ultimate aims were boldly utopian, his immediate political strategy was in key respects cautious and gradualistic. He was highly sceptical of orthodox, individualistic liberalism, yet he believed that there was much to be gained from cooperation with and support for 'advanced' Liberals. Thus, 'the official Liberal attitude is one thing, and the great mass of Good Will and broad thinking in the ranks of Liberalism and the middle class quite another. ${ }^{85}$ That good will could be courted effectively by socialists only if they refrained from electoral activity and instead taught the socialist 'habit of mind' in order that 'all parties and public institutions' would become 'in different measure socialist parties and tools. ${ }^{86}$ Hence his apparent sympathy for certain aspects of the Liberal government's reform agenda, his assertion of the compatibility of liberalism and socialism, his courting of Chiozza Money, and his active support for Churchill. And hence perhaps, the comment of the prominent Liberal H.W. Massingham, editor of The Nation, who had himself left the Fabians in 1893, on his breach with the Society: 'I'm sorry for progress and glad for literature you're out. ${ }^{87}$ This also helps 
explain why Wells was accused by some socialists of having 'gone over bag and baggage to the "permeators,", 88 and was criticized for meditating 'on the good that may be got from Liberals and Conservatives. ${ }^{89}$

\section{'A Liberal by nature and necessity'}

Well's post-Fabian phase was to see him articulate the liberal aspect of his political identity more explicitly. He satirized the Liberal Party freely in his fiction, and criticized it in his non-fiction. But he also engaged constructively with Liberal ideas, and his work attracted a growing interest amongst advanced Liberals. By September 1914 he was writing unselfconsciously of 'we Liberals' - and this was by no means a new departure. ${ }^{90}$

Wells's engagement with Liberal thought is demonstrated by his interaction with Hilaire Belloc's ideas. Belloc does not fit easily into accounts of the New Liberalism; indeed whether or not he was ever a truly liberal thinker is a moot point. (In 1910 he stood down as an MP, strongly disillusioned with parliamentary politics. His subsequent attacks on the government over the Marconi scandal were influenced by his anti-Semitism.) Yet, as a member of the Commons, he believed his own Liberalism was 'so advanced' that socialists could pose no electoral threat to him; and he strongly supported Lloyd George's radical 1909 Budget. ${ }^{91}$ Furthermore, in 1908, Wells identified Belloc and his fellow Christian, the writer G.K. Chesterton, as representative of the 'non-capitalist section of the Liberal Party' to which he himself wished to appeal. 'If Belloc and Chesterton are not Socialists, they are at any rate not anti-Socialists', he wrote, adding: 'Their organised Christian State is nearer the organised State I want than our present plutocracy. ${ }^{92}$ 
Belloc features in the Wells literature mainly on account of the two men's dispute over the latter's Outline of History (1920), but it is clear that in the pre-war period they shared a mutual respect. ${ }^{93}$ And Belloc undoubtedly influenced Wells's thinking about social reform. When Beatrice Webb, who was a member of the Royal Commission on the Poor Law, produced her famous Minority Report in 1909, Wells joined the National Committee for the Prevention of Destitution that was established to try to get it put into effect. ${ }^{94}$ The report recommended breaking up the poor law and distributing its functions to specialized bodies, and the establishment of Ministry of Labour to co-ordinate the employment market. There was also a coercive element, in that the able-bodied unemployed would receive maintenance only if they agreed to undertake training, and those convicted of vagrancy, mendacity or the neglect of their families were to be forced into the new Ministry's detention colonies. Belloc launched his attack on the ensuing Prevention of Destitution Bill in the New Age in April 1910, claiming that it would produce lead to the establishment of the 'servile state', in which the mass of the workers would gain economic security only at the expense of their liberty. ${ }^{95}$ Wells now changed his tune. In the interview (mentioned above) that he gave to the Labour Leader the following month, he admitted that Belloc's criticisms were 'unmistakably damaging.' The proposals for training colonies 'sounded disagreeably like State serfdom'. He attacked the 'District Visitor spirit' of the Fabians, and agreed with the interviewer's suggestion that there was 'a Fabian tendency to be in too great a hurry to get big changes' in advance of the development of the 'Socialist thought and sentiment' needed for them to function properly'. ${ }^{96}$ This was in line with his contemporaneous letter to The Young Liberal: 'Socialism without 
Liberalism is organisation without liberty [...] Liberalism without Socialism is generosity in a vacuum and freedom in a waterless desert. ${ }^{97}$

Although it might be tempting to dismiss Wells's use of the 'servile state' terminology as a mere personal dig at the Webbs, ${ }^{98}$ it is clear that Belloc had struck a chord with him. At the same time, his reaction to the 'servile state' idea was not one that Belloc himself could endorse. In 1912, Wells edited a collection of essays entitled The Great State - a term he now preferred to 'socialism' or 'the socialist state'. He proposed, in order to avoid one class of the community being condemned to act as a servile labouring class, 'a general conscription and a period of public service for everyone'. ${ }^{99}$ Unsurprisingly, Belloc disagreed. ${ }^{100}$ It is striking, though, that The Nation expressed its 'profound sympathy' with much of what Wells had to say, and found his solution to the labour question highly desirable: 'It is just, honest, and, on the face of things, technically feasible. ${ }^{101}$ In other words, his ideas could receive a fairly warm reception from one of the bastions of the New Liberalism.

Wells was not of course satisfied with the Liberal Party as it stood. The New Machiavelli - serialized from May 1910 onwards, and published in volume form the following year - contains some of his most famous strictures upon it. The hero, Richard Remington, is elected as Liberal MP in 1906, but becomes disillusioned with the party: 'It was tremendously clear what they were against. The trouble was to find out what on earth they were for!' Remington also disapproves of 'our self-satisfied new Liberalism and Progressivism. ${ }^{, 102}$ However, the suggestion that the book is 'an anti-Liberal tract' is unconvincing. ${ }^{103}$ It clearly did reflect some of Wells's own views. In particular, its hero champions 'the Endowment of Motherhood' - an idea 
that Wells also argued for elsewhere - i.e. state subsidies paid directly to mothers, conditional on them meeting certain child-care standards, in order to stimulate the production of 'good-quality children'. ${ }^{104}$ But we must not forget its status as a novel, as Wells himself emphasized: 'The New Machiavelli is a work of fiction \& [...] Remington is an attempt to express the ideas of Tory Democracy in an intellectualized coherent form.' He stated that 'Remington is not H.G. Wells but just simply himself' ${ }^{105}$ It would wrong to downplay the book's importance for this reason. Fiction gave Wells scope for playfulness and ambiguity and his use of it is one thing that marks him out from Hobson, Hobhouse et al. Nevertheless, we should not read the book naively as a pure statement of Wells's own personal credo and, in trying to understand his thinking about the New Liberalism, we need to pay due attention to his non-fiction writings too.

Some of his most interesting comments can be found in a series of articles on 'The Labour Unrest' that he published in the Daily Mail in May 1912. He sought to diagnose the then-current wave of industrial discontent, which he felt was directed against the whole economic and social system rather than aimed at limited and specific objectives. He attributed the growing distrust between classes in part to the workers' awareness of economic inequalities, spectacularly symbolized by the recent Titanic disaster, in which the Third Class passengers perished disproportionately. $\mathrm{He}$ also attacked the government: 'With our whole social order in danger, our legislature is busy over the trivial little affairs of the Welsh Established Church, whose endowment probably is not equal to the fortune of any one of half a dozen Titanic passengers or a tithe of the probable loss of another strike among the miners. ${ }^{, 106} \mathrm{He}$ believed that a shift in consciousness on behalf of the rulers was required: 'the only 
way to a better understanding and co-operation, the only escape from a social slide towards the unknown possibilities of Social Democracy, lies in an exaltation of the standard of achievement and of the sense of responsibility in the possessing and governing classes. It is not so much "Wake up England!" that I would say as "Wake up, gentlemen!", 107 He played down his own socialism: 'I theory I am a Socialist, and were I theorizing about some nation in the air I would say that all the great productive activities and all the means of communication should be national concerns and be run as national services.' However, the British state was 'peculiarly incapable of such functions' and therefore 'In the default of our public services, there opens an immense opportunity for voluntary effort. ${ }^{, 108}$

Wells further called for a 'National Plan', 'co-partnery' between labour and employees in industry, 'a compulsory period of labour service for everyone', and argued for proportional representation (PR) for Westminster elections. ${ }^{109}$ The articles generated much public interest. Given their emphasis on moral reformation of the elite, as opposed to drastic upheaval, it is perhaps unsurprising that some prominent Liberals found much of his analysis compelling, even if they thought his concrete proposals underwhelming. Charles Masterman (of whom more later) wrote to him that the articles were ' $D$----- $d$ good in criticism - quite the best stuff you have been doing $-[\ldots]$ but yr. remedies leave me cold. ${ }^{110}$ The cabinet minister J.A. Pease - an Asquith loyalist - thought the articles 'a wonderfully brilliant diagnosis of the cause \& reason of unrest - but I was awfully disappointed at his conclusions \& his remedies.' Pease cast doubt on Wells's radicalism: 'He claims to be a socialist, yet he realises men must have a self-interest in their own work for themselves, he even asks for royalties to be given them for further specialization by improvements in 
laboursaving machinery. ${ }^{, 11}$ That idea was not, perhaps, inherently incompatible with socialism, but it was certainly true that, taken in isolation, many of Wells's proposals appeared incrementalist rather than millenarian. (He did, however, attack 'all of these eight-hour-a-day, early closing, guaranteed-weekly-half-holiday notions that are now so prevalent in Liberal circles', on the absurd grounds that if he personally was ordered to hew a thousand tons of coal he would rather get all the work out of the way as fast as possible without being forced to take a break. ${ }^{112}$ When Wells reacted to the public debate he had triggered, he stressed that he was not a 'panacea-monger'. He wrote: 'No violent changes, no Napoleonic saviour can carry on the task of building the Great State, the civilised State, that rises out of our disorders. ${ }^{, 13}$

In a further, highly significant article in June 1913, Wells's socialism receded further into the background, as he simultaneously trumpeted his liberalism and disparaged the Liberal Party itself. This was during the Marconi scandal, which involved dubious share-dealing by Lloyd George and Rufus Isaacs, the Attorney-General. Wells's article is worth quoting at length:

Liberalism is sick and ashamed of its party. [...]

Liberalism, I hold, is the natural prevailing faith of the mass of English people. It is always in the majority in the country, and only at times through the failure of its "party" to do it justice is it in a political minority. I declare myself a Liberal by nature and necessity; it is a far deeper, more essential thing in me than the Socialism of my dreams or the Collectivism of my economics. And it is with the mass of honest Liberalism, which is the substance of England, that I find myself in revolt against the party.

Wells felt that Lloyd George and Isaacs had, in their original behaviour, made only 'very trivial errors indeed'. It was the subsequent cover-up that was reprehensible. 'We Liberals want no more explanations and no more disputing and vindicating and 
defying;' he argued; 'we want to get rid of this spirit of party trickery altogether.' To that end - and this cannot have endeared him to many Liberal MPs - the party should go out of office, for 'in the bracing wilderness of Opposition a chastening reconstruction may become possible., 114

When war broke out in 1914, Wells supported British involvement. For this he was attacked by many, including some Liberals in the columns of The Nation. In October, despairing of his critics, he sent a letter to the paper's editor, declaring that he would give up contributing to it: 'I would as soon play croquet with Alice in Wonderland as go on with these ridiculous attempts to reason with Liberals about Liberalism. ${ }^{115}$ This appears to have struck one of his best-known biographers as the authentic note of his attitude to contemporary Liberalism. ${ }^{116}$ Yet the remark can only be properly appreciated when it is recognized that Wells saw himself not as an outsider, berating people who he took to be his natural opponents, but as a Liberal himself, wrangling unprofitably with those he thought should naturally support him. Hence his use, during his debates with them, of the phrase 'We Liberals'. Indeed, on the question of the war, he was much more in tune with mainstream Liberal opinion (at least within parliament) than his pacifist critics were. Significantly, he chose to write on the war in the Daily News, the Daily Chronicle and The Nation 'as I think those papers reach the doubtful "liberal" public which I can best influence. ${ }^{, 17}$ The fact that he had for years been in an almost perpetual state of irritation with the Liberal Party and many of those within it should not of course be ignored. Yet it hardly made him unique among Liberals, for many of whom grumbling about the party's direction was an addictive habit. Dissatisfaction with the status quo, moreover, was wholly compatible with, if not actually a precondition of, being a reforming New Liberal. For unless one was 
dissatisfied with the present condition of liberalism, why would one wish to subject it to radical change? Indeed, it is Wells's demand that the Liberal Party undergo 'a chastening reconstruction' that establishes firmly his credentials as a New Liberal, as this demonstrates not simply that he was discontented with contemporary liberalism, but also, crucially, that he thought it worth saving.

\section{Wells's influence on Liberal politicians}

So far, we have seen that Wells frequently identified himself as a Liberal; that he viewed socialism as an integral part of liberalism; and that at times (at least in 1913) placed a higher priority on liberalism than socialism. He also advocated a number of specific reforms that were in fact put into place by the Liberal government. None of this implied an uncritical attitude towards either government or party. Clearly - as he himself suggested to Wallas in 1901 - he was a Liberal sui generis. Yet, idiosyncrasies notwithstanding, the vital Liberal dimension to his thought helps explain why major figures within the party found themselves in fundamental sympathy with many his views. Wells was also met by indifference and at times hostility, but even these reactions are sometimes revealing of where Wells stood within the Liberal spectrum.

This is not the place for a complete discussion of the reception of Wells's ideas by Liberals, or for a full history of his personal relations with the figures concerned. It will suffice to give a few prominent examples of his influence. Churchill represents a key instance. It is common knowledge that he was a friend of Wells and read his work, but nobody has ever suggested that the latter influenced his thinking about social questions. ${ }^{118}$ Proof of such influence can, however, be found in Churchill's 
reaction to A Modern Utopia. Although the book was published in 1905, Churchill did not find time to read it until his holidays the following year. On 9 October 1906 he wrote to Wells about it: 'there is so much in your writing that stimulates my fancy that I owe you a great debt, quite apart from the courtesy \& kindness of your present. Especially did I admire the skill and courage with which the questions of marriage \& population were discussed. ${ }^{119}$

Two days after writing to Wells, Churchill gave a speech in Glasgow - one that is generally seen as a landmark in his conversion to the New Liberalism. ${ }^{120} \mathrm{He}$ declared boldly that 'The cause of the Liberal Party is the cause of the left-out millions', and spoke of the need of the state to concern itself with the care of children, the sick and the aged. Like Wells, he used the terminology of evolution: 'The existing organisation of society is driven by one mainspring - competitive selection., ${ }^{121}$ There were also direct verbal similarities with Wells's work. Some of these may have been no more than commonplaces. For example, Wells argued that 'To the onlooker, both Individualism and Socialism are, in the absolute, absurdities ... the way of sanity runs, perhaps even sinuously, down the intervening valley. ${ }^{122}$ Churchill likewise noted that 'It is not possible to draw a hard-and-fast line between individualism and collectivism.' ${ }^{123}$ There were also more striking similarities. Wells wrote: 'The State will stand at the back of the economic struggle as the reserve employer of labour'. ${ }^{124}$ Churchill said: 'I am of the opinion that the State should increasingly assume the position of the reserve employer of labour. ${ }^{, 25}$ Wells argued: 'Whatever we do, man will remain a competitive creature [...] no Utopia will ever save him completely from the emotional drama of struggle, from exultations and humiliations, from pride and prostration and shame. [...] but we may do much to make the margin of failure 
endurable." ${ }^{, 26}$ Churchill said: 'I do not want to see impaired the vigour of competition, but we can do much to mitigate the consequences of failure.' Churchill also spoke of 'the vision of a fair [i.e. beautiful] Utopia which cheers the hearts and lights the imagination of the toiling multitudes'. ${ }^{127}$ This explicit use of the term 'Utopia', so soon after he had read A Modern Utopia, seems unlikely to have been a mere coincidence.

On the evidence presented here, it seems clear that Wells's ideas did have a significant direct effect on the way that Churchill articulated his views on social reform. If so, Wells's decision (discussed above) to support Churchill, rather than the socialist candidate, in the 1908 by-election, is rendered yet more explicable. Although his belief that Churchill was in full accordance with the socialist spirit was of course unjustified, he nonetheless did have genuine evidence that Churchill's mind was 'developing and broadening' in line with his own ideas.

Lloyd George presents an equally interesting case, although a less clear-cut one. It is well known that Frances Stevenson, with whom he began a thirty-year affair in 1913, was much influenced by Wells, and perhaps especially by Ann Veronica. ${ }^{128}$ Prior to meeting her, Lloyd George had already shown an interest in Wells's work. This is demonstrated by an entry in the diary of Lucy Masterman (wife of Charles Masterman) from December 1910: 'George admires Wells's writings tremendously. "He is the only writer whose opinions on politics interests me in the least," he said, "I think he is the greatest writer of today." ${ }^{129}$ There is other evidence of his familiarity with, and liking for, Wells's writings. ${ }^{130}$ In 1912, Charles Masterman told Wells that Lloyd George was continually pressing for a meeting with him. ${ }^{131}$ They did meet on a 
number of occasions, and Wells confessed to 'a strong but qualified affection' for Lloyd George. ${ }^{132}$ But, as Stevenson noted in 1934, they never seemed 'really to hit it off when they meet. There is a clash of intellects, which is disappointing. ${ }^{133}$ All the same, there seems no real reason not to take Lloyd George's remark to Lucy Masterman at face value. It is not difficult to believe that he should have preferred Wells's vivid style to that of, say, Hobson and Hobhouse. In other words, we should take seriously the evidence of Lloyd George's sympathy with Wells's ideas, even if we cannot trace their impact on him in detail.

Charles Masterman's own enthusiasm for Wells, personally and ideologically, was manifest. Wells thought Masterman a 'rather miserable exceptional' person, ${ }^{134}$ and later recalled that he was one those who stuck by him during the uproar provoked by Ann Veronica. ${ }^{135}$ Masterman's and Wells's world-views overlapped to a great extent, even though Masterman was a committed Christian and Wells a scientific humanist. ${ }^{136}$ The former's response to Love and Mr. Lewisham and to Anticipations was a trifle ambivalent, ${ }^{137}$ but by 1905 he was describing Wells as 'that most courageous and individual of all social prophets'. ${ }^{138}$ He admired both A Modern Utopia and Kipps. ${ }^{139}$ The critique of Edwardian affluence in Tono-Bungay also struck a profound chord; the book denounces the 'waste' of capitalism and the smallness of conventional values. ${ }^{140}$ In 1922 , Masterman recalled reading the proofs on the train after visiting Wells at Folkestone: 'I could scarcely refrain from shouting out and brandishing it in the faces of the bewildered passengers, as I realised I had got hold of a masterpiece. ${ }^{141}$ 
Masterman's approval of Wells's work was of political as well as literary significance. In 1903, he made a first, unsuccessful, attempt at getting into the Commons, fighting a by-election campaign at Dulwich. In the course of doing so, he spoke to a group of local parents. He told Wells afterwards: 'I quoted freely in my lecture from your new book [...] and urged all the unhappy parents to read it. ${ }^{142}$ This book was Mankind in the Making, much of which focussed on the problem of education. Clearly, this occasion was not of the same level of significance as Churchill's Glasgow speech. But it was, nonetheless, another clear example of a New Liberal politician absorbing parts of Wells's message and relaying them to the public. Similarly, Masterman's book The Condition of England (1909) was peppered with references to Wells's work. Wells, in Masterman's view, successfully depicted a world that, although calm on the surface, was exhibiting fractures that portended cataclysmic change. ${ }^{143}$ Masterman himself told Wells: 'I believe we have an enormous amount in common: and have felt again and again in reading your work this is exactly what I have been wanting to say - and unable to say it., ${ }^{144}$

Chiozza Money too was in close sympathy with Wells. The latter's enthusiasm for Money's work has already been noted. It led to a warm friendship between them. ${ }^{145}$ Significantly, during the Fabian episode, Wells's efforts to persuade Money to join the Society were successful. In 1908 Wells nominated him as a candidate for the executive; he was elected, and served for three years. ${ }^{146}$ Furthermore, in 1912 Money contributed an essay to Wells's book The Great State. Like Wells, he feared that 'Without culture of a kind which is not now possessed even by our ruling classes' there was a risk that a socialist society would turn out to be nothing more than a 'Servile State'. ${ }^{147}$ At the same time, he endorsed Wells's idea of 'The Great State', 
which, in Money's words, meant that 'the whole of the adult population should be organised to produce a high minimum standard of life, and that such organisation would yield to the whole community not only the materials of such a standard but a quality and degree of leisure and liberty at present undreamed of., ${ }^{148}$ In 1918, Chiozza Money joined the Labour Party, but his career did not prosper. He later came to sympathise with Mussolini, which led to a cooling of his friendship with Wells. ${ }^{149}$ This should not, however, be allowed to disguise the fact that, as Money wrote to Wells in 1934, 'There was a time when our ideas were much in common' ${ }^{150}$

There were some Liberals, like J.A. Pease - whose comments on Wells's 1912 articles were noted above - whose reactions were ambivalent. There were others, like Asquith, who were indifferent to Wells's thinking, or who at least left no record of their views. But there was little outright hostility, and even much of that was provoked by Wells's private behaviour rather than by his ideas. Herbert Samuel later recalled the social ostracism to which Wells was subjected once his affair with Reeves became known. After that, Wells was no longer asked to Samuel's dinner parties at the House of Commons or at his house, 'and if one saw Wells in the street one passed him by., ${ }^{151}$ Presumably, though, he would not have been inviting Wells to dinner parties in the first place unless he had thought that he had some worthwhile things to say. Even the exceptions, then, help prove the rule - that although no Liberal would have endorsed Wells's writings in their entirety, his thinking about society resonated strongly with those of them who were 'advanced'. And, whereas the evidence for the influence of the 'classic' New Liberal intellectuals is often circumstantial and ambiguous, it can be shown in a very concrete way that MPs and ministers were reading Wells, paying 
attention to his ideas, and even quoting him in speeches. He undoubtedly deserved the label later given him by C.P. Snow: 'The great educator of unlikely people'. ${ }^{152}$

\section{Conclusion}

By highlighting Wells's forgotten commitment to regenerating Liberalism, this article has shown how such resonance was possible. Why has the liberal aspect of his identity been neglected for so long? The New Machiavelli - a reliable source of colourful quotation - has probably been too influential in conditioning scholars' views of what Wells thought about the Liberal Party. His comments in it need to be handled with a good deal of caution, and should not be taken as straightforward statements of his beliefs - which can at any rate easily be found elsewhere in his writings. In part, moreover, Wells's liberalism may have been further obscured by what in some ways looks like a post-Edwardian leftward turn in his thinking. After his visit to the Soviet Union in 1920 he was portrayed by his political opponents (now including Churchill) as an apologist of Lenin; and he stood unsuccessfully as a Labour parliamentary candidate in 1922 and 1923. All the same, his rhetorical commitment to liberalism did not end. Even when standing as a Labour candidate, he declared that 'I would as soon call myself a Liberal, for the two terms are quite compatible. ${ }^{153}$ In November 1927 he was chided by the Assistant Secretary of the Labour Party for backing a Liberal candidate in a by-election, and later the same month he argued for a Liberal-Labour coalition government with Philip Snowden as Prime Minister. ${ }^{154}$ His 1932 suggestion of the development of a 'Liberal Fascisti' was hardly his finest hour; but that he chose to make his call for a 'Phoenix Rebirth' of Liberalism at the Young Liberal Summer School suggests that he had not completely given up on the Liberal Party as an institution. ${ }^{155}$ He wrote in 1935 that 'There is as it were a pause in liberal progress, a 
pause between the great liberal drive of the nineteenth century $[\ldots]$ and the renascent Liberalism of the twentieth century which will carry us on to the planned economy of a unified and pacified world. ${ }^{156}$ In his 'auto-obituary', published in 1937 and again in 1943, Wells wrote of himself: 'He was a Liberal Democrat in the sense that he claimed an unlimited right to think, criticise, discuss, and suggest, and he was a Socialist in his antagonism to personal, racial, or national monopolisation. ${ }^{157}$ When Wells died in 1946, it was perhaps Robin Page Arnot, in his Daily Worker obituary, who got closest to accurate assessment of his political views. He wrote: 'He was a kind of Socialist, and also a kind of Liberal, and most frequently took the standpoint of an independent progressive'. ${ }^{158}$

It is not, of course, argued here that Wells was not a socialist. He certainly thought that he was, just as he sincerely believed he was a Liberal. The crucial point is that he was by no means unique in thinking that one could, without contradiction, be both. This was in fact quite a common New Liberal trope. ${ }^{159}$ As Peter Clarke has observed, 'At the beginning of the second decade of the twentieth century it looked as though both Labour and Liberalism would be subsumed in progressivism. ${ }^{160}$ Political identities were often blurred. For example, the young Fabian socialists Rupert Brooke and Hugh Dalton 'hero-worshipped' Masterman, thinking of him 'as the young leader of the Radical-Socialist wing of the Liberal Party, which, we hoped, would soon split off and join the Labour Party to make a real Socialist Party in Britain.' They clearly did not think that their socialism was incompatible with their membership of the National Liberal Club, where Dalton met with Wells (and appreciated his mockery of the Webbs). ${ }^{161}$ Hobson, likewise, believed that the Liberal government's reforms could fairly be described as 'socialistic', and thought the party doomed unless it 
further embraced the radicalism of the advanced guard. ${ }^{162}$ Hobhouse spoke tentatively of the possibility of a 'liberal socialism'. ${ }^{163}$ Churchill, in his 1906 Glasgow speech, argued that Liberals should not shy away from radical reforms 'just because some old woman comes along and tells you they are Socialistic.' Each case of state control versus private enterprise should be judged on its merits, he argued. ${ }^{164}$ Peter Clarke's observation that some 'senses of "socialism" [...] were acceptable to Liberals' is highly relevant here. ${ }^{165}$ Wells's ideas found a receptive New Liberal audience because his version of liberal socialism spoke to many of its concerns.

Nevertheless, if Wells was a New Liberal, and an influential one, he could never be part of the party's establishment. He himself illustrated the point - literally - in a cartoon which, we may guess, dates from around the time of his election to the National Liberal Club. He drew himself in the guise of a tramp, sitting on the steps of the Club, being harassed by a policeman. Wells is saying: 'Move on Sir? But there was a gentleman Sir, said I should be let in Sir, if I'd wait a minute Sir. Seemingly I went to sleep Sir. ${ }^{166}$ Although some of the Liberal government's actions, and the views of some of its radical members, gave him grounds for hope that the party might ultimately be converted into a vehicle for his ideas, the realities of the Liberal electoral coalition meant that this was never a credible ambition. Leo Chiozza Money recalled of his own efforts to rally advanced Radical opinion in the 1906 Parliament: 'there did not seem to be enough collectivists to go round. ${ }^{, 167}$ Although Wells received an attentive and sympathetic hearing in important quarters, that remark could also serve as an epitaph on his own quest to reconstruct and reinvigorate Edwardian Liberalism. 
${ }^{1}$ I am grateful to John S. Partington, who made insightful comments on earlier drafts of this article, and provided me with a wealth of useful information. Glen Leonard also gave me some valuable pointers, as did three anonymous referees. Any errors that remain are of course my own responsibility. I am also grateful to the Trustees of the Trevelyan Papers in the Robinson Library, University of Newcastle, for permission to quote from the correspondence between H.G. Wells and C.P. Trevelyan.

${ }^{2}$ Wells's letter to The Young Liberal was reproduced in The Manchester Guardian on 14 May 1910.

${ }^{3}$ S.D. Shallard, 'Mr. H.G. Wells on the Prevention of Destitution Bill', The Labour Leader, 13 May 1910.

${ }^{4}$ John Burns to H.G. Wells, 16 May 1910, Burns Papers, British Library, MS Add. 46301, f. 121.

${ }^{5}$ H.G. Wells, Mankind in the Making (London, 1903), 20.

${ }^{6}$ See Norman and Jeanne MacKenzie, The Time Traveller: The Life of H.G. Wells (London, 1973), 256.

${ }^{7}$ See Michael Freeden, The New Liberalism: An Ideology of Social Reform (Oxford, 1978).

${ }^{8}$ See, for example, Steven McLean, "“The fertilising conflict of individualities": H.G. Wells's A Modern Utopia, John Stuart Mill's On Liberty and the Victorian Tradition of Liberalism', Papers on Language and Literature, 43 (2007), 166-189, and Philip Coupland, 'H.G. Wells's "Liberal Fascism"', Journal of Contemporary History, 35 (2000), 541-558.

${ }^{9}$ For example, W. Warren Wagar, in his influential book H.G. Wells and the World State (New Haven, 1961, 226-37), devotes several pages to Wells's views on 'Welfare in Utopia', but fails to consider how his opinions may have been influenced by contemporary debates about welfare legislation, both in and outside Parliament.

${ }^{10}$ William J. Hyde, 'The Socialism of H. G. Wells in the Early Twentieth Century', Journal of the History of Ideas, 17 (1956), 217-234 at 217. This assumption permeates, amongst other works, Gordon D. Feir's H.G. Wells at the End of his Tether: His Social and Political Adventures (New York, 2005).

${ }^{11}$ See, for example, David C. Smith, H.G. Wells: Desperately Mortal: A Biography (New Haven and London, 1986), 96, 111, 116, 133.

${ }^{12}$ Patrick Parrinder 'H.G. Wells and Beatrice Webb: Reflections on a Quarrel', The Wellsian, 1 (1976), 11-17 at 16.

${ }^{13}$ Maurice Cowling, Religion and Public Doctrine in Modern England Vol. II: Assaults (Cambridge, 1985), 216.

${ }^{14}$ The most significant biographies are: Geoffrey West, H.G. Wells: sketch for a portrait (London, 1930); Lovat Dickson, H.G. Wells: His Turbulent Life and Times (London, 1969); MacKenzie and MacKenzie, Time Traveller; Anthony West, H.G. Wells: Aspects of a Life (London, 1984); Smith, H.G. Wells; Michael Coren, The Invisible Man: The Life and Liberties of H.G. Wells (London, 1993); and Michael Foot, H.G.: The History of Mr. Wells (London, 1996).

${ }^{15}$ Geoffrey West, H.G. Wells, 163-4, 190.

${ }^{16}$ See, for example, Michael Freeden, 'Eugenics and Progressive Thought: A Study in Ideological Affinity', Historical Journal, 22 (1979), 645-671, at 656.

${ }^{17}$ For Huxley's influence on Wells's social thought see John S. Partington, 'The Death of the Static: H. G. Wells and the Kinetic Utopia', Utopian Studies, 11 (2000), 96-111. Concern with evolution was not of course unique to the New Liberals. See, in 
particular, David Stack, The First Darwinian Left: Socialism and Darwinism 18591914 (Cheltenham, 2003).

${ }^{18}$ Peter Clarke, Liberals and Social Democrats (Cambridge, 1978),128-31; Kenneth

O. Morgan, '1906: "Blissful Dawn”?', Journal of Liberal History, 51 (20060, 32-7, at 34.

${ }^{19}$ For a discussion of such links, see David Blaazer, The Popular Front and the Progressive Tradition: Socialists, Liberals, and the Quest for Unity, 1884-1939 (Cambridge, 1992).

${ }^{20}$ David Marquand, 'MacDonald, (James) Ramsay (1866-1937)', Oxford Dictionary of National Biography, Oxford University Press, Sept 2004; online edn, May 2007 [http://www.oxforddnb.com/view/article/34704, accessed 13 Dec 2007]

${ }^{21}$ See, for example, 'Mr. Philip Snowden', Manchester Guardian, 7 Oct. 1911.

${ }^{22}$ For Wells's view of Keeling, see his introduction to E. T. (E. Townshend) (ed.), Keeling Letters \& Recollections (London, 1918).

${ }^{23}$ MacKenzie and MacKenzie, Time Traveller, 64.

${ }^{24}$ H.G. Wells, Anticipations of the Reaction of Mechanical and Scientific Progress Upon Human Life and Thought (Mineola NY, 1999, originally published 1901), 163. ${ }^{25}$ Samuel Hynes, The Edwardian Turn of Mind (London, 1991, originally published by Princeton University Press, 1968), 94; H.G. Wells, 'Faults of the Fabian', 1906, reproduced in ibid., 390-409.

${ }^{26}$ H.G. Wells to W.T. Stead, 31 Oct. 1901, quoted in Joseph O. Baylen, 'W.T. Stead and the early career of H.G. Wells, 1895-1911', Huntingdon Library Quarterly, 38 (1974), 53-59, quotation at 61.

${ }^{27}$ H.G. Wells to Winston Churchill, 19 Nov. 1901, in David C. Smith (ed.), The Correspondence of H.G. Wells Volume 1: 1880-1903 (London, 1998), 457.

${ }^{28}$ H.G. Wells to Graham Wallas, 13 Dec. 1901, Graham Wallas Papers, 1/28/1, British Library of Political and Economic Science (henceforward BLPES). Both the question marks are Wells's.

${ }^{29}$ Wells to Wallas, 20 April 1902, Wallas Papers, 1/28/2; Smith, H.G. Wells, 97.

${ }^{30}$ Carole Seymour-Jones, Beatrice Webb: Woman of Conflict (London, 1992), 260.

${ }^{31}$ Wells, Mankind, 93, 115; H.G. Wells to Charles Booth, 2 [or 12?] Feb. 1902, Charles Booth papers, Senate House Library, University of London, MS 797/I/6100.

${ }^{32}$ Wells, Mankind, 32, 283-4

${ }^{33}$ H.G. Wells, A Modern Utopia (London, n.d., first published 1905), 99-100, 155-6.

${ }^{34}$ Hyde touches on this point but does not develop it: 'The Socialism of H. G.

Wells', 227.

${ }^{35}$ Wells, Mankind, 29-30.

${ }^{36}$ C.P. Trevelyan to H.G. Wells, 1 May 1905, H.G. Wells Papers, University of Illinois, M-409.

${ }^{37}$ H.G. Wells to C.P. Trevelyan, 2 May 1905, C.P. Trevelyan Papers, Robinson Library, Newcastle upon Tyne, CPT Ex 51/11.

${ }^{38}$ H.G. Wells to C.P. Trevelyan, 22 June 1905, Trevelyan Papers, CPT Ex 51/18.

${ }^{39}$ MacKenzie and MacKenzie, Time Traveller, 184-6.

${ }^{40}$ Wells, Mankind, 31.

${ }^{41}$ Memorial to A.J. Balfour, 20 Nov. 1905, Herbert Samuel Papers, SAM A/23/49, House of Lords Record Office (HLRO).

${ }^{42}$ A useful introduction to his career is provided by Martin Daunton, 'Money, Sir Leo George Chiozza (1870-1944)', Oxford Dictionary of National Biography, Oxford University Press, Sept 2004; online edn, Jan 2008 
[http://www.oxforddnb.com/view/article/55929, accessed 21 Feb 2008]. However, Chiozza Money has not received the attention he deserves in the wider historiography.

${ }^{43}$ H.G. Wells, 'This Misery of Boots', The Independent Review, 7 (1905), 396-413, at 413.

${ }^{44}$ H.G. Wells to Leo Chiozza Money, 6 Dec. 1905, Leo Chiozza Money Papers, Add. 9259/IV/60, Cambridge University Library.

${ }^{45}$ Edward R. Pease, the History of the Fabian Society ( ${ }^{\text {rd }}$ edition, London, 1963), 163.

${ }^{46}$ See, for example, Margaret Cole, The Story of Fabian Socialism (London, 1961), 117-24; Norman and Jeanne MacKenzie, The First Fabians (London, 1977), 328-52; Patricia Pugh, Educate, Agitate, Organise: 100 years of Fabian socialism (London, 1984), 82-93. The same is true of Wells's biographers.

${ }^{47}$ George Mariz, 'The Fabians and the "Episode of Mr. Wells"', Research Studies, 51 (1983), 83-97; Hyde, 'The Socialism of H. G. Wells', 218-9; Hynes, Edwardian Turn of Mind, 106.

${ }^{48}$ Dickson, H.G. Wells, 125

${ }^{49}$ Wells, 'Faults', 401.

${ }^{50}$ Ibid., 397.

${ }^{51}$ Ibid., 393.

${ }^{52}$ Dickson, H.G. Wells, 117. See also Hynes, Edwardian Turn of Mind, 110.

${ }^{53}$ Wells to Chiozza Money, 10 Oct. 1906, Chiozza Money Papers, Add. 9259/IV/61.

54 'Report of the Special Committee' (1906), Fabian Society Papers, B/5/2, BLPES.

${ }^{55}$ Pease, History, 170.

${ }^{56}$ George Bernard Shaw to Sidney Webb, 25 Nov. 1906, Passfield Papers, 2/4/C/3/196-7, BLPES. Pease's later account implied that Shaw's proposal was of little significance, and subsequent writers, if they mention it at all, have likewise skated over it. Certainly, it did not command unanimous support even amongst the 'Old Gang', but Wells clearly thought it an important (and dangerous) proposal, and his own stance cannot be understood unless this is appreciated. Pease, History, 178, 180; MacKenzie and MacKenzie, First Fabians, 335; Smith, H.G. Wells, 109.

${ }^{57}$ H.G. Wells, 'Reconstruction of the Fabian Society', n.d. but between 7 and 14 Dec. 1906, MS. Add. 62992, ff. 3-8, British Library. This remark may help make sense of Ben Keeling's contemporary belief that Wells was advocating 'that middle and upper class Socialists should throw in their lot with the Labour Party': E.T., Keeling Letters, 14.

${ }^{58}$ H.G. Wells, 'Socialism and Politics', The Socialist Review, June 1908, 250-6, at 252-3.

${ }^{59}$ R.C.K. Ensor, Sydney Olivier, S.D. Shallard, Mrs. W. Pember Reeves and H.G. Wells, 'Executive Committee Election', n.d., 1907, Fabian Society Papers, B5/4/14.

${ }^{60} \mathrm{H}$. Granville Barker et al, 'The Fabian Society: Election of Executive Committee, 1907-8', n.d., 1907, Fabian Society Papers, B5/4/18.

61 'Discarded section of Fabian Society Address (Executive old gang). Feb. 1907', Shaw Papers, British Library, MS Add. 50681 ff. 8-11.

${ }_{62}^{6}$ Pease, History, 179.

63 'Fabian Legends', Daily News, 11 March 1907.

64 “"The Fabian Legend”: Mr. Bernard Shaw Replies', Daily News, 12 March 1907.

${ }^{65}$ H.G. Wells to the editor of the Daily News, published on 13 March 1907, reproduced in David C. Smith (ed.), The Correspondence of H.G. Wells Volume 2: 1904-1918, Pickering \& Chatto, London, 1998, 142. 
66 'The Career of Fabianism', The Nation, 30 March 1907.

${ }^{67}$ H.G. Wells to the editor of The Nation, 30 March 1907, published on 6 April 1907, reproduced in Smith, Correspondence 2, 145-7.

${ }^{68}$ H.G. Wells to an unknown addressee, 6 March 1907, in Smith, Correspondence 2, 140.

${ }^{69}$ H.G. Wells to Mr. Making (unidentified), 30 March 1907, in Smith, Correspondence 2, 144.

${ }^{70}$ H.G. Wells to Beatrice Webb, Francis Galton et al, 15 May 1907, in Smith, Correspondence 2, 149-51.

${ }^{71}$ H.G. Wells, 'The Socialist Movement and Socialist Parties', The New Age, 13 June 1907.

${ }^{72}$ H.G. Wells, 'About Chesterton and Belloc', The New Age, 11 Jan. 1908

${ }^{73}$ H.G. Wells, Experiment in Autobiography: Discoveries and Conclusions of a Very Ordinary Brain (Since 1866) Vol. II (London, 1984, originally published 1934), 660.

${ }^{74}$ I.e. the recently renamed Social Democratic Federation.

${ }^{75}$ David C. Smith, 'Winston Churchill and H.G. Wells: Edwardians in the Twentieth Century', Cahiers Victoriens et Edouardien, 30 (1989), 93-116 at 99. See also

Lisanne Radice, Beatrice and Sidney Webb: Fabian Socialists, Macmillan, London, 1984, 178, and Foot, H.G., 88-9. Anthony West however correctly notes Wells's view that Churchill was 'open-minded and educable': H.G. Wells, 315.

${ }^{76}$ Winston Churchill, 'The Untrodden Field in Politics', The Nation, 7 March 1908.

${ }^{77}$ Wells, 'The Socialist Movement and Socialist Parties', The New Age, 13 June 1907.

${ }^{78}$ H.G. Wells, 'An Open Letter to an elector in N. W. Manchester', Daily News, 21 Apr. 1908.

${ }^{79}$ Pease, History, 163 n. 1; MacKenzie and MacKenzie, First Fabians, 351-2.

${ }^{80}$ H.G. Wells, 'Socialism and Politics', The Socialist Review, June 1908, 250-6, at 253-5. See also H.G. Wells to the editor of Christian Commonwealth, published 12 May 1909, in Smith, Correspondence 2, 239-40, in which he defended the ILP's leaders against the party's more radical members, such as Victor Grayson.

81 'Wells's draft March 1908', Shaw Papers, Add. 50681, ff. 27-8.

${ }^{82}$ G.B. Shaw to H.G. Wells, 10 March 1908, in J. Percy Smith (ed.), Selected Correspondence of Bernard Shaw: Bernard Shaw and H.G. Wells, University of Toronto Press, Toronto, 1995, 63.

${ }^{83}$ H.G. Wells to E.R. Pease, 16 Sept. 1908, in Smith, Correspondence 2, 223-4.

${ }^{84}$ For the negative attitude of the Webbs towards the Children Act, see Bernard Wasserstein, Herbert Samuel: A Political Life, Clarendon Press, Oxford, 1992, 107.

${ }^{85}$ H.G. Wells, New Worlds For Old, Constable, London, 1908, 353.

${ }^{86}$ H.G. Wells, 'The Socialist Movement and Socialist Parties', The New Age, 13 June 1907.

${ }^{87}$ H.W. Massingham to H.G. Wells, n.d., 1908, quoted in Smith, H.G. Wells, 110; Clarke, Liberals, 43.

${ }^{88}$ Cecil Chesterton, 'The Need for a Socialist Party', The New Age, 20 June 1907.

${ }^{89}$ G.R.S. Taylor, Leaders of Socialism Past and Present (London, 1908), 15.

Discussion of whether Wells was really advocating the traditional Fabian policy of 'permeation' could easily become bogged down in quasi-theological dispute, as the concept had always meant different things to different people. It should be noted, though, that Wells emphatically denied the charge. What is indisputable is that he believed that, whilst socialists should identify themselves as such, this did not imply the need for 'separatism in party politics': H.G. Wells to the editor of the New Age, 
published 27 June 1907, in Smith, Correspondence 2, 153-55. See also Mark Bevir, 'Fabianism, Permeation and Independent Labour', Historical Journal, 39 (1996), 17996.

${ }^{90}$ H.G. Wells, 'The Two Ways', The Nation, 12 Sept. 1914.

${ }^{91}$ Victor Feske, From Belloc to Churchill: Private Scholars, Public Culture, and the Crisis of British Liberalism, 1900-1939 (Chapel Hill, NC, 1996), 28, 59; A.N.

Wilson, Hilaire Belloc (London, 1984), 183.

${ }^{92}$ Wells, 'About Chesterton and Belloc', The New Age, 11 Jan. 1908.

${ }^{93}$ See Hilaire Belloc, 'A Letter to Wells', and H.G. Wells, 'Nominalist and Realist', both in The New Age, 17 Dec. 1908. See also Belloc's pre-war letters to Wells, Wells Papers, B-176.

${ }^{94}$ H.G. Wells to Beatrice Webb, 22 Feb. 1909 and Wells to Beatrice Webb late Feb. 1909, in Smith, Correspondence 2, 235-6; 'Poor Law Reform: A National "Minority" Committee', The Times, 27 May 1909. Chiozza Money was also a member.

${ }^{95}$ Hilaire Belloc, 'The Prevention of Destitution Bill', The New Age, 14 April 1910. Belloc's book The Servile State was published in 1912.

${ }^{96}$ Shallard, 'Mr. H.G. Wells on the Prevention of Destitution Bill', The Labour Leader, 13 May 1910. The interview disproves Smith's contention that Wells 'never wavered in his public support' for the Minority Report: Correspondence 2, $236 \mathrm{n} .2$ (emphasis in original).

${ }_{97}^{97}$ Manchester Guardian, 14 May 1910.

${ }^{98}$ As hinted by Wagar, H.G. Wells and the World State, 232, n. 46.

${ }^{99} \mathrm{He}$ anticipated that this period would be short, perhaps a year: H.G. Wells, 'The

Past and the Great State', in H.G. Wells et al, The Great State: Essays in

Construction, Harper \& Brothers, London, 1912, 3-46, at 39.

${ }^{100}$ Hilaire Belloc, 'The Great State', The Eye-Witness, 20 June 1912.

101 'Pot-Shots at Utopia', The Nation, 15 June 1912. Wells was not, however, grateful for the review, which he thought gave a misleading account of his earlier ideas: H.G.

Wells to the editor of The Nation, published 12 June 1912, reproduced in Smith, Correspondence 2, 327-8.

${ }^{102}$ H.G. Wells, The New Machiavelli (Leipzig, 1911), Vol. II, 31, 20.

${ }^{103}$ Cowling, Religion and Public Doctrine Vol. II, 216.

${ }^{104}$ H.G. Wells, 'The Endowment of Motherhood', Daily Mail, 22 June 1910.

${ }^{105}$ H.G. Wells to an unknown addressee, n.d. [1911], in Smith, Correspondence 3, 311. See also H.G. Wells, 'The Future of the Novel, 11 Dec. 1927, in H.G. Wells, The Way the World is Going: Guesses \& Forecasts of the Years Ahead (London, 1928), 282-92, and John Hammond, A Preface to H.G. Wells (Harlow, 2001), 142.

${ }^{106}$ H.G. Wells, 'The Labour Unrest', in Daily Mail, What the Worker Wants: The Daily Mail Enquiry, (London, n.d. but 1912), 13.

${ }^{107}$ Ibid., 12-13.

108 Ibid., 26

${ }^{109}$ Ibid., 21-7.

${ }^{110}$ C. F. G. Masterman to H.G. Wells, 'Sunday $25^{\text {th }}$ [1912], Wells papers, M-228.

111 J.A. Pease to Pamela McKenna, 30 May 1912, Reginald McKenna Papers,

Churchill College, Cambridge, MCKN 9/4.

${ }^{112}$ H.G. Wells, 'Syndicalism or Citizenship', in Daily Mail, What the Worker Wants, 119.

${ }^{113}$ H.G. Wells, 'The craving for One Simple Cheap Remedy', in Daily Mail, What the Worker Wants, 108. 
${ }^{114}$ H.G. Wells, 'What are Liberals to do?, Daily Mail, 19 June 1913.

${ }^{115}$ H.G. Wells to the editor of The Nation, published 3 Oct. 1914, in Smith,

Correspondence 2, 387-8.

${ }^{116}$ Smith, H.G. Wells, 133.

${ }^{117}$ H.G. Wells to Lord Northcliffe, n.d., 1916, Northcliffe Papers, British Library, MS Add.62161, f. 95.

118 Paul K. Alkon does acknowledge that the men's 'views sometimes coincided', especially when it came to the impact of science on warfare, but he argues that this was 'a matter of imaginative affinities rather than influence': Winston Churchill's Imagination (Lewisburg, 2006), 167-8. For the personal relationship, see Smith, 'Winston Churchill and H.G. Wells'.

${ }^{119}$ Winston Churchill to H.G. Wells, 9 Oct. 1906, Wells Papers, C-238-2.

${ }^{120}$ Paul Addison, Churchill on the Home Front 1900-1955 (London, 1992), 57.

${ }^{121}$ Winston Churchill, speech of 11 Oct. 1906, in Robert Rhodes James (ed.),

Churchill Speaks: Winston S. Churchill in Peace and War: Collected Speeches, 1897-

1963 (Leicester, 1981), 105-111.

${ }^{122}$ Wells, Modern Utopia, 92.

${ }^{123}$ Churchill, speech of 11 Oct. 1906.

${ }^{124}$ Wells, Modern Utopia, 141.

${ }^{125}$ Churchill, speech of 11 Oct. 1906.

${ }^{126}$ Wells, Modern Utopia, 139.

${ }^{127}$ Churchill, speech of 11 Oct. 1906.

${ }^{128}$ Frances Lloyd George, The Years that Are Past (London, 1967), 36. See also John Campbell, If Love Were All...The Story of Frances Stevenson and David Lloyd

George (London, 2006), 7-8.

129 Lucy Masterman diary, 8 Dec. 1910, Masterman Papers, University of Birmingham Special Collections, CFGM 29/2/2/2.

${ }^{130}$ A. J. P. Taylor (ed.), Lloyd George: A Diary by Frances Stevenson (New York, 1971), 13 (entry for 30 Nov. 1914).

${ }^{131}$ C. F. G. Masterman to H.G. Wells, 'Sunday $25^{\text {th }}$ [1912], Wells Papers, M-228.

132 'The Re-Emergence of Mr. Lloyd George', 8 Dec. 1923, in H.G. Wells, A Year of Prophesying (London, 1924), 71.

133 Taylor, Lloyd George: A Diary, 286 (entry for 31 Oct. 1934). See also C. F. G.

Masterman, 'H.G. Wells', Review of Reviews, 15 June 1922.

${ }^{134}$ H.G. Wells to G.K. Chesterton, n.d., probably 1916, Chesterton Papers, British Library, MS Add 73199, f. 29.

${ }^{135}$ Wells, Experiment Vol. II, 471.

${ }^{136}$ For Wells's views see Willis B. Glover, 'Religious Orientations of H.G. Wells: A Case Study in Scientific Humanism', Harvard Theological Review 65 (1972), 117 135.

${ }^{137}$ Lucy Masterman, C. F. G. Masterman: A Biography (London, 1939), 34; C.F.G.

Masterman, review of Anticipations, The Commonwealth, 7 (1902), 25-7.

${ }^{138}$ C. F. G. Masterman, In Peril of Change: Essays Written in Time of Tranquillity (London, 1905), 320.

${ }^{139}$ C. F. G. Masterman, 'The Day of Better Things' (review of A Modern Utopia), Daily News, 11 Apr. 1905; C. F. G. Masterman, 'A Book of the Day' (review of Kipps), Daily News, 25 Oct. 1905.

${ }^{140}$ Masterman's debt to it is noted briefly in MacKenzie and MacKenzie, The Time Traveller, 243. 
${ }^{141}$ Masterman, 'H.G. Wells'.

142 C. F. G. Masterman to H.G. Wells, 4 Nov. 1903, Wells Papers, M-228.

${ }^{143}$ C. F. G. Masterman, The Condition of England (London, 1909), 25, 150, 234-7, 282-3.

${ }^{144}$ C. F. G. Masterman to H.G. Wells, 11 May 1905, Wells Papers, M-228.

${ }^{145}$ Leo Chiozza Money, 'On the Brink of War' (unpublished memoirs, preface dated 1939), Money Papers, MS Add. 9259, f. 378.

${ }^{146}$ H.G. Wells to Edward Pease, 14 March 1908, Fabian Society Papers, A9/3/29;

Pease, History, 286. Money served again in 1919-22.

${ }^{147}$ L.G. Chiozza Money, 'Work in the Great State', in Wells et al, The Great State, 69-119, at 101.

${ }^{148}$ L.G. Chiozza Money, The Future of Work and other essays, (London, 1914), v.

${ }^{149}$ Money, 'On the Brink', f. 378; L.G. Chiozza Money to H.G. Wells, 18 and 24 Feb. 1927, Wells Papers, M-409.

${ }^{150}$ L.G. Chiozza Money to H.G. Wells, 6 Nov. 1934, Wells Papers, M-409.

${ }^{151}$ Frank Singleton, record of a conversation with Herbert Samuel, 6 Feb. 1939,

Herbert Samuel Papers, HLRO, SAM A/161.

${ }_{152}$ C.P. Snow, Variety of Men (London, 1967), 57.

${ }^{153}$ H.G. Wells, 1923 election address (misdated 1922) in Harry W. Laidler (ed.),

Wells's Social Anticipations (New York, 1927), 133.

154 J.S. Middleton to H.G. Wells, 11 Nov. 1927, J.S. Middleton Papers, JSM/Wel/1,

Labour History Archive and Study Centre, Manchester; H.G. Wells, 'Baldwinism a

Danger to the World', 27 Nov. 1927, in Wells, The Way the World is Going, 84-93.

${ }^{155}$ Coupland, 'Liberal Fascism', 542-3; H.G. Wells, After Democracy: Addresses and Papers on the Present World Situation (London, 1932), 24, 2-3. See also H.G. Wells to Lord Esher, 31 Oct. and 2 Nov. 1935, in David Smith (ed.), The Correspondence of H.G. Wells Vol. 4 (London, 1998), 45-49.

${ }^{156}$ H.G. Wells, 'Impression of Masaryk', Naše doba, 42 (1935), 321-2.

${ }^{157}$ H.G. Wells, 'My Auto-Obituary', The Strand, 104A (1943), 45-7, reproduced in J.

R. Hammond (ed.), H. G. Wells: Interviews and Recollections (London and Basingstoke, 1980), 117-19.

${ }^{158}$ R. Page Arnot, 'He Always Fought the Old Order', Daily Worker, 14 Aug. 1946.

${ }^{159}$ See Freeden, New Liberalism, 25-75.

${ }^{160}$ Peter Clarke, Lancashire and the New Liberalism (Cambridge, 1971), 406.

${ }^{161}$ Hugh Dalton, Call Back Yesterday: Memoirs 1887-1931 (London, 1953), 40-1, $74-$ 5.

162 J.A. Hobson, The Crisis of Liberalism: New Issues of Democracy (London, 1909), $133-5$.

163 James Meadowcroft (ed.), L.T. Hobhouse: Liberalism and other writings

(Cambridge, 1994), 80, 83-4.

${ }_{164}$ Churchill, speech of 11 Oct. 1906.

${ }_{165}$ Peter Clarke, Hope and Glory: Britain 1900-1990 (London, 1996), 44.

${ }^{166}$ Cartoon, addressed to Graham Wallas, n.d., 1903?, Wallas Papers, 1/28/27.

${ }^{167}$ Money, 'On the Brink', f. 330. 